\title{
CRTC1/MAML2 Fusion Protein
}

National Cancer Institute

\section{Source}

National Cancer Institute. CRTC1/MAML2 Fusion Protein. NCI Thesaurus. Code C99742.

A fusion protein (1024 aa, 112 kDa) encoded by the CRT C1/MAML2 fusion gene. This protein is comprised of the first $42 \mathrm{~N}$-terminal amino acids of the CREB-regulated transcription coactivator 1 protein fused to most of the mastermind-like protein 2. 